\title{
Evaluation of NPSB Fertilizer Levels on Yield and Yield Components of Open Pollinated Maize (Zea mays L.) Varieties Under Irrigated Condition in South Omo Zone
}

\author{
Awoke Tadesse $e^{1, *}$, Muhaba Sultan ${ }^{2}$ \\ ${ }^{1}$ Department of Agronomy, Southern Agricultural Research Institute, Jinka Agricultural Research Center, Jinka, Ethiopia \\ ${ }^{2}$ Department Soil Science, Southern Agricultural Research Institute, Jinka Agricultural Research Center, Jinka, Ethiopia
}

Email address:

awoketadese3@gmail.com (A. Tadesse)

*Corresponding author

To cite this article:

Awoke Tadesse, Muhaba Sultan. Evaluation of NPSB Fertilizer Levels on Yield and Yield Components of Open Pollinated Maize (Zea mays

L.) Varieties Under Irrigated Condition in South Omo Zone. American Journal of BioScience. Vol. 9, No. 3, 2021, pp. 86-94.

doi: 10.11648/j.ajbio.20210903.13

Received: March 31, 2021; Accepted: June 2, 2021; Published: June 10, 2021

\begin{abstract}
Maize is a significant cereal crop in Ethiopia. However, the yield of this crop is limited due to lack of varieties and blended fertilizer for varieties and site specifications. The use of exact amount of fertilizer based on crop requirement has significant importance for sustainable crop production. A study was undertaken to investigate the effects of NPSB blended fertilizer rate for maize yield production in Dasenech and Nyangatom districts in the lowland area of South Omo Zone, Southern Ethiopia during the 2019/2020 cropping season. The experiment was factorial with three maize varieties (Melkassa6Q Melkassa-4 and Melkassa-2) and four NPSB blended fertilizer rates including $\mathrm{kg} \mathrm{ha}^{-1}$ (none fertilizer, 50NPSB, 100NPSB and 150 NPSB). Factorial combinations were used as twelve treatments laid out in a randomized complete block design with three replications. Growth, yield and yield components parameters were recorded and carried out statistical analysis The result of analysis of variance revealed that the interaction effect of varieties and blended fertilizer rate highly significant difference in grain yield. The result showed that the highest grain yield $\left(3913.3 \mathrm{~kg} \mathrm{ha}^{-1}\right)$ and net benefit $\left(49,229.6\right.$ Eth-birr ha $\left.{ }^{-1}\right)$ with MRR of $2525.83 \%$ were obtained from Melkassa-2 variety treated with $100 \mathrm{~kg} \mathrm{ha}^{-1}$ of NPSB fertilizer rates at Dasenech location. Whereas, at Nyangatom location, the highest grain yield $\left(4906.7 \mathrm{~kg} \mathrm{ha}^{-1}\right)$ and net benefit $\left(62640.45 \mathrm{Eth}-\mathrm{birr} \mathrm{ha}^{-1}\right)$ with MRR of $2926.2 \%$ were obtained from similar Melkassa-2 variety treated with $100 \mathrm{~kg} \mathrm{ha}^{-1}$ of NPSB fertilizer levels s. Therefore, based on the result recorded from this study Melkassa-2 varieties treated with $100 \mathrm{~kg} \mathrm{ha}^{-1}$ of NPSB blended fertilizer can be suggested as profitable for the production of maize at both districts of the study areas and their similar soil conditions and agroecology.
\end{abstract}

Keywords: NPSB Fertilizer, Open Pollinated Maize Varieties, Profitability, Grain Yield

\section{Introduction}

'Maize (Zea mays L.) is a member of the grass family, Poaceae. It is believed that the crop was originated in Mexico and introduced to West Africa in the early $1500 \mathrm{~s}$ by the Portuguese traders" [1]. It was brought to Ethiopia in the 1600 s to 1700 s [2]. In Ethiopia agriculture, 'maize is one of the pillars cereal crops ranking first in total production and productivity, and second to teff in area coverage" [3]. Maize in Ethiopia is used directly for human consumption as food or local drinks. In addition, maize leaves are used for feed to animals and dry stalks are used as fuel and for the construction of fences [4].

In the year 2017, maize was grown on about $322,714.36$ ha of land in SNNP Region from which 1,085,725.3 tons were produced, with a regional average yield of $3.36 \mathrm{t} \mathrm{ha}^{-1}$. During the same year, 22,396.77 ha was covered with maize in South Omo Zone and about 53,973.28 tones were produced, making the zonal average yield $2.41 \mathrm{tha}^{-1}$ [5]. This yield is far less than the attainable yield ( 7 to $8 \mathrm{t} \mathrm{ha}^{-1}$ ) under good management conditions [6]. The low yield of maize in Ethiopia is attributed to several production constraints which 
include shortage of improved varieties, poor crop management practices, unbalanced nutrient application, diseases and insect pests [7].

Low soil fertility highly negatively "affects the growth and development of maize as compared to other crops. As a result, it is often said" maize speaks" implying that maize cannot produce maximum yields unless sufficient nutrients are available" [8]. When the soil does not supply sufficient nutrients for normal plant growth application of supplemental nutrients is required. In fact, the response of maize plants to the application of fertilizers varies from variety to variety, location to location, and also depends on the availability of the nutrients [9].

Better matching fertilizer application recommendations to local climate, soil, and management practices help ensure that production can be intensified cost-effectively and sustainably [10]. Hence, understanding the plant nutrients requirement of a given area has a vital role in enhancing crop production and productivity on a sustainable basis. However, in the current study area all agro-pastoralist use their own local variety with no fertilizer application which results in poor grain yield in quality and quantity. Therefore, the main objective of the study was to evaluate the effects of NPSB blended fertilizer rates on yield, yield component and its profitability of selected maize varieties under irrigated conditions in the lowland area of South Omo zone.

\section{Materials and Methods}

\subsection{Description of the Study Area}

The field experiment was implemented in Dasenech and
Nyangatom woreda of the lowland area of South Omo zone during the 2019/20 cropping season. Astronomically, Dasenech woreda found lying roughly between $4^{\circ} 37^{\prime}-4^{\circ} 48^{\prime}$ North latitude and $35^{\circ} 56^{\prime}-36^{\circ} 20^{\prime}$ East longitude, and Nyangatom between $5^{\circ} 05^{\prime}-5^{\circ} 21$ 'North latitude and $35^{\circ} 55^{\prime}-$ $36^{\circ} 14^{\prime}$ East longitude, respectively. The altitude of the areas varies between 353m.a.s.1-606m.a.s.l for Dasenech, and 380m.a.s.1-497m.a.s.1 for Nyangatom district, respectively. According to the districts' agricultural and natural resource office, the climate in these areas is dominantly a semiarid type. The district has very small, erratic and variable rainfall and high ambient temperature. But at Nyangatom woreda no agro metrological date due to the absence of an agrometrology station. In Dasenech districts the rainfall pattern is bimodal, with a primary rainy season between March to May and secondary small rain between September to December (see figure 2). In these two woredas (administrative districts) the major livestock raring, agro-pastorals widely practice rain-fed, flood retreat (nowadays very rarely) and irrigated agriculture. They grow Sorghum in number one place followed by Maize and horticultural crops like a banana.

\subsection{Experimental Design and Treatments}

The experiment was laid out factorial with three pollinated maize varieties (Melkassa-6Q Melkassa-4 and Melkassa-2) and fertilizer rate formulated by four blended fertilizer rates including $\mathrm{kg} \mathrm{ha}^{-1}$ (none fertilizer. 50NPSB+ $100 \mathrm{Urea}, 100 \mathrm{NPSB}+100 \mathrm{Urea}$ and $150 \mathrm{NPSB}+100 \mathrm{Urea})$. Factorial combinations were used as twelve treatments arranged in a randomized complete block design (RCBD) with three replications.

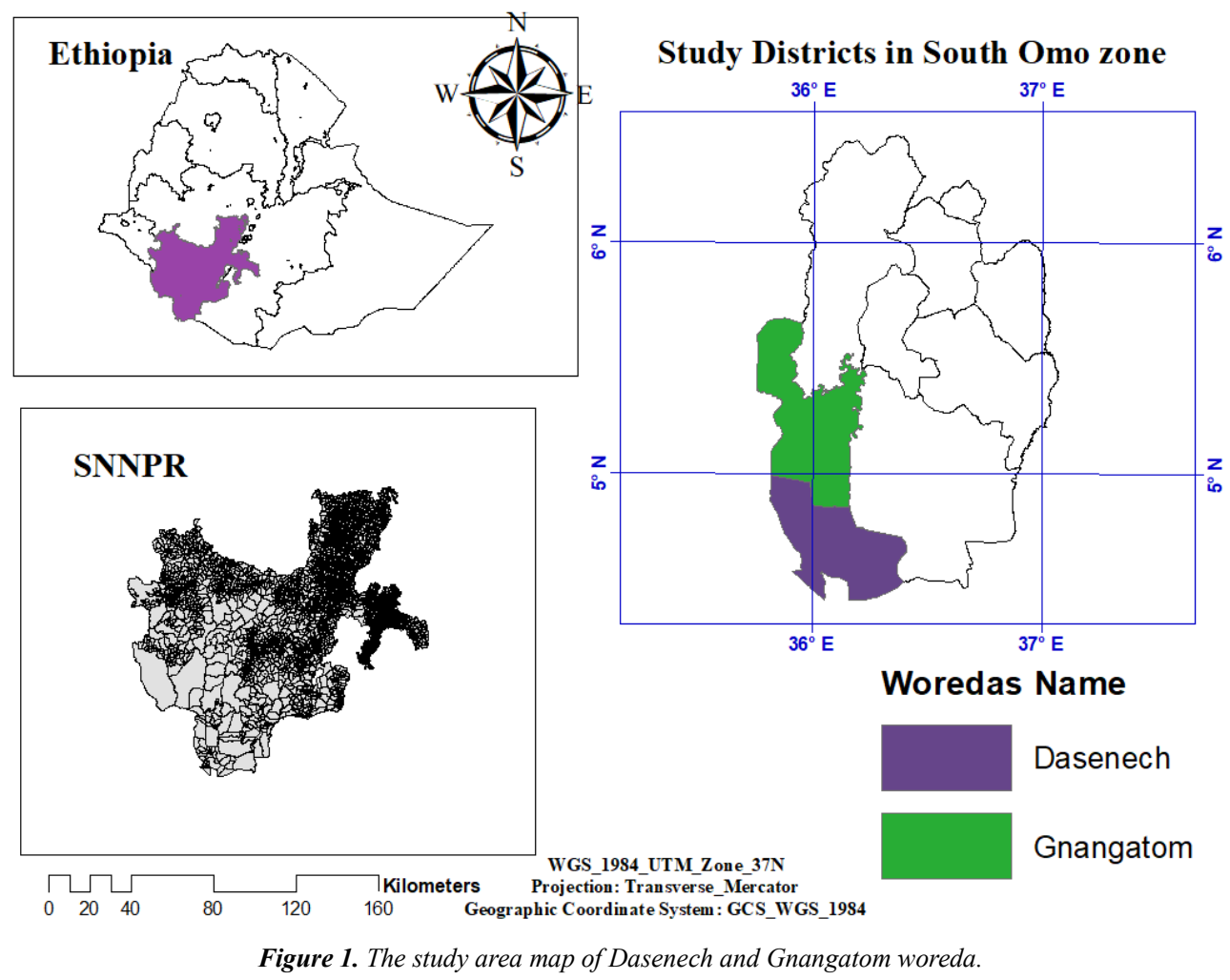




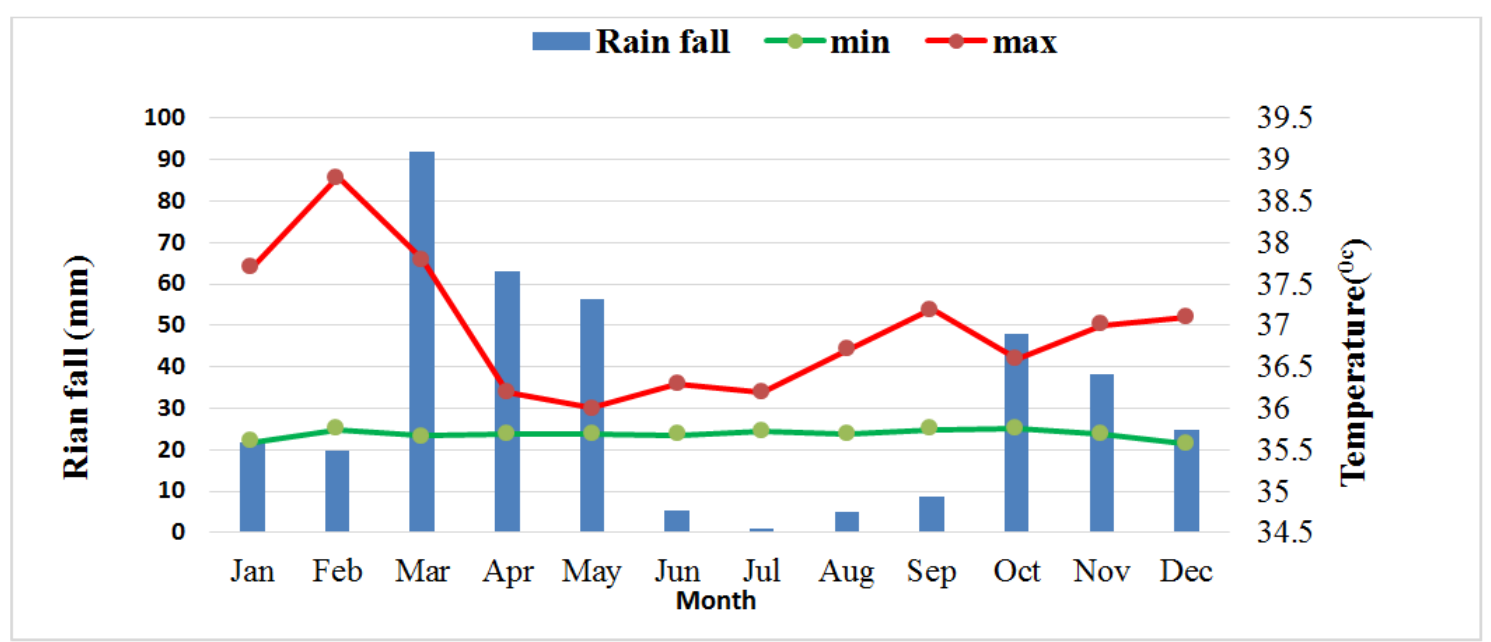

Figure 2. Monthly rainfall, minimum and maximum temperature at Dasenech distinct (2000-2019 G.C).

\subsection{Experimental Procedure and Management}

The land was ploughed twice, disked and harrowed once and ridged with $75 \mathrm{~cm}$ by tractor, after which the furrow was corrected by labor. The two seeds were sown at $25 \mathrm{~cm}$ intrarow spacing and $75 \mathrm{~cm}$ inter-row spacing. Thinning was done 15 days after emergence to maintain the target plant densities. Blended fertilizer rates were applied at planting and urea fertilizer was applied at stem elongation in a constant rate (i.e., $50 \mathrm{Kg} \mathrm{ha}^{-1}$ ). The gross plot size of the experiment was $5 \mathrm{~m} \times 5 \mathrm{~m}\left(25 \mathrm{~m}^{2}\right)$. The spacing between replications and plots was $2.0 \mathrm{~m}$. Plots were furrow irrigated every 5-7 days from planting up to flowering and then every 8-10 days up to physiological maturity according to weather condition at Omorate location while at Weyito location, 6-8 days from planting up to flowering and then every 9-11 days up to physiological maturity according to weather condition. Three-time Ethiozinon (Diazinon) $60 \%$ E.C was applied at the rate of $1.5 \mathrm{~L} \mathrm{ha}^{-1}$ into the leaf using a knapsack sprayer to control fall armyworm. The first, second and third weeding and hoeing were performed 20,45 and 65 days after emergence, respectively. The net harvestable row was 5 (five) excluding the border two rows.

\subsection{Data Collection}

\subsubsection{Soil Data}

A soil sample was collected in which $1 \mathrm{Kg}$ composite soil sample from each location for reprehensive of all experimental plots before planting. Collected soil samples were air-dried at room temperature, grounded using mortar and pistil, and passed through a $2 \mathrm{~mm}$ diameter sieve for the analyses of selected physic-chemical soil properties using conventional laboratory methods. The laboratory analysis was carried out in Areka Agricultural Research Center, and the analyzed soil parameters include soil texture, soil $\mathrm{pH}$, Total Nitrogen (TN), Organic carbon, available Phosphorus, available Potassium, available Sulfur and available Boron. Soil texture was determined by the Boycouos hydrometric method [11, 12] after destroying $\mathrm{OM}$ using hydrogen peroxide $\left(\mathrm{H}_{2} \mathrm{O}_{2}\right)$ and dispersing the soils with sodium hexametaphosphate $\left(\mathrm{NaPO}_{3}\right)$.
The $\mathrm{pH}$ of the soil was measured potentiometrically using a digital $\mathrm{pH}$ meter in the supernatant suspension of 1:2.5 soil to water ratio. Total $\mathrm{N}$ was analyzed using the Kjeldahl digestion, distillation and titration method as described by [13] by oxidizing the $\mathrm{OM}$ in concentrated sulfuric acid solution $(0.1 \mathrm{~N}$ $\mathrm{H}_{2} \mathrm{SO}_{4}$ ), and whereas organic carbon was determined following the Walkley-Black wet digestion method as described by [14]. Available phosphorus was determined by the Olsen procedure [15], and that of sulfate $\left(\mathrm{SO}^{2-}\right)$ of soil samples was analyzed turbid metrically by calcium chloride dehydrate using the method described in the soil survey manual [16]. Available Potassium was determined after extracting the soil samples by ammonium acetate $(1 \mathrm{~N}$ $\mathrm{NH}_{4} \mathrm{OAc}$ ) at $\mathrm{pH}$ 7.0, and Boron in soil was done by dilute $\mathrm{HCl}$ methods.

\subsubsection{Plant Data}

\section{(i). Growth Traits}

Measured plant height during physiological maturity from central rows as the mean height of five randomly takensample plants from the ground level to the apex of each plant. Ear height of five random plants was measured from the base of plants to the node bearing the uppermost useful ear and the average value was recorded in $\mathrm{cm}$. The ear length of five randomly taken ears was measured from ears attached to the stalk to the tip of the ear in $\mathrm{cm}$ and the average was used.

\section{(ii). Yield Components}

The number of ears per plant was determined from five randomly sampled plants and the average value was considered. Total above-ground dry biomass yield $(\mathrm{kg})$ was determined by taking the total weight of the harvest including the seeds from five central rows and sun drying the biomass to constant weight and converted to $\mathrm{t} \mathrm{ha}^{-1}$. Hundred seed weight (g) was weighed by taking the weight of hundred randomly sampled seeds from the five harvested central rows and adjusted to $12.5 \%$ moisture content.

\section{(iii). Grain Yield}

The five central rows per plot were harvested, sun-dried 
and threshed. The grain yield in $\mathrm{kg}$ from each plot was weighed using an electronic balance. Seed moisture content was measured with a moisture meter (DRAMINSKI SN: 10-
860 Olsztyn) after which the grain weight was adjusted to $12.5 \%$ moisture level content and converted to $\mathrm{t} \mathrm{ha}^{-1}$. The adjusted yield was calculated using [17] formula.

$$
\text { Adjusted grain yield }(\mathrm{kg})=\frac{\text { Actual yield }(\mathrm{kg}) *(100-\text { Actual moisture content })}{(100-\text { standard moisture content of cereal }(12.5 \%)}
$$

Harvest index (HI) was computed as the ratio of adjusted grain yield to total above-ground dry biomass [18].

$$
\mathrm{HI}=\frac{\text { Adjusted grain yield ton } / \mathrm{ha}}{\text { above }- \text { ground dry biomass ton } / \mathrm{ha}}
$$

\subsection{Statistical Analysis}

The collected data were subjected to analysis of variance "(ANOVA) for appropriate to factorial experiment in a randomized complete block design (RCBD) using SAS software program version 9.2" [19] with a generalized linear model (GLM) procedure. Means were separated using the least significant differences (LSD) test at 5\% level of significance.

\subsection{Economic Analysis}

The "cost of other production practices like, watering and weeding were assumed to remain the same or insignificant among the treatments. Analysis of the marginal rate of return (MRR\%) was carried out for non-dominated treatments, and the MRRs were compared to a minimum acceptable rate of return (MARR) of $100 \%$ to select the optimum treatment" [20]. The net benefit per hectare for each treatment is the difference between the gross benefit and the total variable costs. The average yield was adjusted downward by $10 \%$ to reflect the difference between the experimental field and the expected yield at farmers' fields and with farmer's practices from the same treatments [20].

\section{Result and Discussion}

\subsection{Physico-Chemical Properties of the Experimental Soil Before Planting}

Laboratory analysis result of selected soil Physicochemical properties before planting was indicated in table 1 below. The result indicated that the soil texture class of the study site in Dasenech was sandy clay loam (sand 44\%, silt $28 \%$ and clay $28 \%$ ), and in the Nyangatom sites, it was found to be clay loam (sand $38 \%$, silt $30 \%$ and clay $32 \%$ ) (Table 1 ). The $\mathrm{pH}$ of the sites was in the moderately to slightly acidic range (6.0-6.6) $[21,22]$. The organic carbon content of the soils was $0.9 \%$ and $0.23 \%$ for Dasenech and Nyangatom sites, respectively. In addition, the soils of the study sites contained total nitrogen content of $0.08 \%$ for Dasenech and $0.02 \%$ for Nyangatom; and available Phosphorus contents of $6.15 \mathrm{mg} \mathrm{Kg}^{-1}$ for Dasenech and $6.68 \mathrm{mg} \mathrm{Kg}^{-1}$ for Nyangatom, respectively. The result showed that available Potassium, Sulfur and Boron content; for the Dasenech site was 58.90 $\mathrm{mg} \mathrm{Kg}{ }^{-1}, 2.14 \mathrm{mg} \mathrm{Kg}^{-1}$ and $0.16 \mathrm{mg} \mathrm{Kg}^{-1}$, respectively and
For Nyangatom was $54.43 \mathrm{mg} \mathrm{Kg}^{-1}, 18.19 \mathrm{mg} \mathrm{Kg-1}$ and 0.26 $\mathrm{mg} \mathrm{Kg}{ }^{-1}$, respectively. As it can be observed from the table below, soils of the Dasenech sites were dominated by sand fractions or coarse texture until $20 \mathrm{~cm}$ depth, and hence they consequently retain few nutrients and have a low waterholding capacity [23]. Therefore, soil management practices which lead to an increase in the fine fraction, lighter but more frequent irrigation and fertilization are generally helpful in improving soil properties and crop productivity, [24]. In addition, as per the ratings by [21], total nitrogen, available phosphorus and potassium were found to be very low and organic carbon was found to be low in the two study sites. Therefore, this, in general, tells us that getting crop yields from all these two study locations would no more be easy without significant fertilization of the soil

Table 1. Laboratory analysis result of selected soil Physicochemical properties before planting.

\begin{tabular}{lll}
\hline & Dasenech & Nyangatom \\
\hline $\begin{array}{l}\text { physical parameters } \\
\text { soil texture }\end{array}$ & Value & Value \\
Sand $(\%)$ & 44.00 & \\
Silt $(\%)$ & 28.00 & 38.000 \\
Clay $(\%)$ & 28.00 & 30.00 \\
Textural class & sandy clay loam & 32.00 \\
Chemical parameters & & clay loam \\
pH & 6.03 & 6.25 \\
Total Nitrogen $(\%)$ & 0.08 & 0.020 \\
Available Phosphorus $(\mathrm{mg} / \mathrm{Kg})$ & 6.15 & 6.68 \\
Available Potassium $(\mathrm{mg} / \mathrm{Kg})$ & 58.90 & 54.43 \\
Available Sulfur $(\mathrm{mg} / \mathrm{Kg})$ & 2.41 & 18.19 \\
Available Boron $(\mathrm{mg} / \mathrm{Kg})$ & 0.16 & 0.26 \\
Organic Carbon $(\%)$ & 0.90 & 0.23 \\
\hline
\end{tabular}

\subsection{Effects of Blended Fertilizer Rate on Growth Parameters of Maize Varieties}

\subsubsection{Plant Height at Maturity}

In this study at Dasenech and Nyangatom location, plant height was significantly $(\mathrm{P}<0.01)$ affected by the main effects of varieties and blended fertilizer rate and significantly $(\mathrm{P}<0.05)$ affected by their interaction of varieties with blended fertilizer rates (Table 2). The tallest plant height $(211.6 \mathrm{~cm})$ and $(237.2 \mathrm{~cm})$ were measured from Melkassa-2 variety treated by with $150 \mathrm{gk} /$ ha of NPSB blended fertilizer rate at Dasenech and Nyangatom location, respectively. While, the shortest plant height $(182.2 \mathrm{~cm})$ and $(179.2 \mathrm{~cm})$ were measured from the Melkassa-4 variety with zero fertilizer at Dasenech and Nyangatom locations, respectively (Table 2). In general, these results showed that, an increase in plant height with increased blended fertilizer rate from 0 to $150 \mathrm{~kg} \mathrm{NPSB} / \mathrm{ha}$ for all tested varieties (Table 2). This increment in plant height might be due to an increase in cell 
elongation and more vegetative growth attributed to different nutrient content. This result was in line with [25] " who indicated that plant growth and development retarded significantly if any of the nutrient elements is less than its threshold value in the soil or not adequately balanced with other nutrient elements". Similarly, [26] "Jeet obtained that, the tallest plant height at the highest fertilizer rate might be fertilizer has a beneficial effect on plant metabolism which affects the physiological process of the crop and thereby increases the growth parameters".

\subsubsection{Ear Height (cm)}

Analyst of variance showed that, ear height was significant variations $(p \leq 0.01)$ among the main effect of varieties and blended fertilizer rate and their interaction at both sites (Table 2). Maximum ear height $(97.5 \mathrm{~cm})$ and $(124.3 \mathrm{~cm})$ were recorded from Melkassa-2 variety with $150 \mathrm{~kg}$ NPSB /ha at Dasenech and Nyangatom location, respectively and minimum ear height $(68.7 \mathrm{~cm})$ was recorded Melkassa-4 with zero blended fertilizer rate at Dasenech location, whereas Nyangatom location, $(95.4 \mathrm{~cm})$ was recorded from Melkassa-
$6 \mathrm{Q}$ variety with zero blended fertilizer rate. As blended fertilizer rates increased from 50 to $150 \mathrm{~kg} \mathrm{ha}^{-1}$ ear height was increased $\mathrm{f}$ in all tested varieties (Table 2 ). This study was conforming to the finding by [27] reported that, blended fertilizers increased similarly ear height of maize increased.

\subsubsection{Ear Length (cm)}

Analyst of variance showed that, ear length was significant variations $(p \leq 0.01)$ among the main effect of varieties and blended fertilizer rate and their interaction at both sites (Table 2). Maximum ear length $(31.2 \mathrm{~cm})$ and $(32.8 \mathrm{~cm})$ were recorded from Melkassa-2 variety with $100 \mathrm{~kg}$ NPSB /ha at Dasenech and Nyangatom location respectively and minimum ear length $(22.1 \mathrm{~cm})$ was recorded Melkassa-4 with zero blended fertilizer rate at Dasenech location, whereas Nyangatom location, $(23.4 \mathrm{~cm})$ was recorded from Melkassa-6Q variety with zero blended fertilizer rate (Table 2). This result was in agreement with the finding by [9] who reported that, the height ear length was obtained from fertilizer treated with compared to zero fertilizer on maize crops.

Table 2. Mean values for interaction effect blended fertilizer rate on the grain yield of OPVS maize varieties at Dasenech and Nyangatom, South Omo Zone during 2019/20 cropping season.

\begin{tabular}{|c|c|c|c|c|c|c|c|}
\hline \multirow[b]{2}{*}{ Varieties } & \multirow{2}{*}{$\begin{array}{l}\text { NPSB Fertilizer } \\
\text { levels (kg/ha) }\end{array}$} & \multicolumn{3}{|l|}{ Dasenech } & \multicolumn{3}{|l|}{ Nyangatom } \\
\hline & & $\begin{array}{l}\text { Plant height } \\
(\mathrm{cm})\end{array}$ & $\begin{array}{l}\text { Ear height } \\
\text { (cm) }\end{array}$ & $\begin{array}{l}\text { Ear length } \\
(\mathrm{cm})\end{array}$ & $\begin{array}{l}\text { Plant height } \\
(\mathrm{cm})\end{array}$ & $\begin{array}{l}\text { Ear height } \\
(\mathrm{cm})\end{array}$ & $\begin{array}{l}\text { Ear length } \\
(\mathrm{cm})\end{array}$ \\
\hline \multirow{4}{*}{ Melkassa-2 } & 0 & $191.8 \mathrm{e}$ & $75.3 \mathrm{~cd}$ & $26.4 \mathrm{cdef}$ & $221.2 \mathrm{~cd}$ & $96.3 \mathrm{fg}$ & $25.7 \mathrm{e}$ \\
\hline & 50NPSB + 100Urea & $195.60 \mathrm{e}$ & $93.9 \mathrm{a}$ & $26.6 \mathrm{cdef}$ & $223.2 \mathrm{~cd}$ & $105.4 \mathrm{~cd}$ & $27.9 \mathrm{~cd}$ \\
\hline & $100 \mathrm{NPSB}+100$ Urea & $205.60 b c$ & $95.5 \mathrm{a}$ & $31.2 \mathrm{a}$ & $230.8 \mathrm{ab}$ & $114.2 \mathrm{~b}$ & $31.8 \mathrm{a}$ \\
\hline & 150 NPSB+100Urea & $211.60 \mathrm{a}$ & $97.5 \mathrm{a}$ & $29.9 \mathrm{ab}$ & $237.2 \mathrm{a}$ & $124.3 \mathrm{a}$ & $29.1 b c$ \\
\hline \multirow{4}{*}{ Mekassa-4 } & 0 & $182.2 \mathrm{f}$ & $68.7 \mathrm{e}$ & $22.1 \mathrm{f}$ & $179.2 \mathrm{~h}$ & $99.3 \mathrm{efg}$ & $23.4 \mathrm{f}$ \\
\hline & 50NPSB+ 100Urea & $182.73 f$ & $79.5 \mathrm{c}$ & $23.6 f$ & $189.3 \mathrm{~g}$ & $100.2 \mathrm{ef}$ & $29.3 b c$ \\
\hline & 100 NPSB+100Urea & $205.80 \mathrm{bc}$ & $88.7 \mathrm{~b}$ & $24.8 \mathrm{def}$ & $213.3 \mathrm{ef}$ & $109.3 \mathrm{c}$ & $28.8 \mathrm{bcd}$ \\
\hline & $150 \mathrm{NPSB}+100$ Urea & $207.60 \mathrm{ab}$ & $96.5 \mathrm{a}$ & $28.8 \mathrm{abc}$ & $216.1 \mathrm{de}$ & $120.4 \mathrm{a}$ & $30.9 \mathrm{ab}$ \\
\hline \multirow{4}{*}{ Melkassa-6Q } & 0 & $184.60 \mathrm{f}$ & $72.7 \mathrm{e}$ & $24.1 \mathrm{ef}$ & $194.4 \mathrm{~g}$ & $95.4 \mathrm{~g}$ & $25.3 \mathrm{e}$ \\
\hline & 50NPSB+ 100Urea & $195.60 \mathrm{e}$ & $76.8 \mathrm{~cd}$ & $24.4 \mathrm{def}$ & $208.2 \mathrm{f}$ & $97.4 \mathrm{eg}$ & $26.9 \mathrm{de}$ \\
\hline & 100 NPSB+100Urea & $197.20 \mathrm{de}$ & $74.5 \mathrm{~d}$ & $27.2 \mathrm{bcde}$ & $221.2 \mathrm{~cd}$ & $100.3 \mathrm{ef}$ & $28.9 \mathrm{bcd}$ \\
\hline & $150 \mathrm{NPSB}+100$ Urea & $201.40 \mathrm{~cd}$ & $85.3 b$ & $27.4 \mathrm{bcde}$ & $228.2 \mathrm{bc}$ & $102.3 \mathrm{de}$ & $29.4 \mathrm{bc}$ \\
\hline $\operatorname{LSD}(0.05)$ & & 5.6432 & 4.2254 & 3.2245 & 7.1700 & 4.3993 & 2.155 \\
\hline
\end{tabular}

\subsection{Yield and Yield Components}

\subsubsection{Above-Ground Dry Biomass Yield $\left(\mathrm{kg}_{\mathrm{ha}} \mathrm{h}^{-1}\right)$}

The main effects of varieties and blended fertilizer rate, as well as their interaction, showed a highly significant $(\mathrm{P}<0.01)$ effect on above-ground dry biomass yield (Table 3 ). The highest above-ground biomass (16977kg/ha) and $(17548 \mathrm{~kg} / \mathrm{ha})$ were recorded from Melkassa-2 variety with $150 \mathrm{~kg} \mathrm{NPSB} / \mathrm{ha}$ at Dasenech and Nyangatom location, respectively and the lowest above ground biomass $(11733 \mathrm{~kg} / \mathrm{ha})$ and $(12403 \mathrm{~kg} / \mathrm{ha})$ were recorded from Melkassa-6Q variety with $0 \mathrm{~kg} \mathrm{NPSB} / \mathrm{ha}$ at Dasenech and Nyangatom location, respectively (Table 3 ). This result is in accordance with [27] who reported that, a significant disparity was observed in biomass yield of maize due to blended fertilizer rate and the highest blended fertilizer rate level was given higher above-ground biomass yield, whereas lowest biomass yield was found where treated with the lowest NPS level.

\subsubsection{Grain Yield (kg/ha)}

The main effects of varieties and blended fertilizer rate, as well as their interaction, showed a highly significant $(\mathrm{P}<$ 0.01 ) effect on grain yield (Table 3 ). This result showed that the responses of grain yield to blended fertilizer rates are quite different among and within varieties. [28] who reported that, there is a genetic variability for maize grain yield to fertilizer level and obtained the genotype $\times$ fertilizer level interaction was significant. The highest grain yield $(3913.3 \mathrm{~kg} / \mathrm{ha})$ and $(4906.7 \mathrm{~kg} / \mathrm{ha})$ were recorded from Melkassa-2 variety with $100 \mathrm{~kg}$ NPSB /ha at Dasenech and Nyangatom location, respectively and the lowest grain yield $(2026.7 \mathrm{~kg} / \mathrm{ha})$ and $(2022 \mathrm{~kg} / \mathrm{ha})$ were recorded from Melkassa-6Q variety with $0 \mathrm{~kg}$ NPSB /ha at Dasenech and Nyangatom location, respectively (Table 3). All tested varieties produced significantly higher mean grain yield as compared to maize varieties planted without blended fertilizer application rate. The higher mean grain yield advantage which was ranged from 18 to $93 \%$ was achieved 
with $100 \mathrm{~kg} /$ ha blended fertilizer application as compared to maize varieties planted without fertilizer application in Dasenech location, while in Nyangatom location mean grain yield advantage of 48 to $142 \%$ were achieved from maize varieties planted with blended fertilizer application as compared to zero (Table 3). This result was in agreement with [28] who "obtained that, mean grain yield advantage of 24 to $66 \%$ was achieved from maize varieties planted with blended fertilizer application as compared to control". [27]) who reported that, grain yields were increased from in maize varieties at fertilizer application levels with compared to without fertilizer application. Similarly, [30] reported that grain yield of maize varieties was increased as fertilizer increased until a certain level.) also "verified that application of blended fertilizer on maize crops brought significantly the highest grain yield as compared to control, standard control of NP and recommended NP $+\mathrm{Cu}+\mathrm{Zn}$ ". Additionally, [31] "found better grain yield from the application of blended fertilizer compare to recommended NP fertilizer and unfertilized plot".

Table 3. Mean values for the effect of the interaction of blended fertilizer rate on the grain yield of OPVS maize varieties in the lowland area, South Omo Zone during 2019/20 cropping season.

\begin{tabular}{|c|c|c|c|c|c|}
\hline \multirow{2}{*}{ Varieties } & \multirow{2}{*}{$\begin{array}{l}\text { NPSB Fertilizer levels } \\
(\mathrm{kg} / \mathrm{ha})\end{array}$} & \multicolumn{2}{|l|}{ Dasenech } & \multicolumn{2}{|l|}{ Nyangatom } \\
\hline & & Biomass (kg/ha) & Grain yield (kg/ha) & Biomass (kg/ha) & Grain yield (kg/ha) \\
\hline \multirow{4}{*}{ Melkassa-2 } & 0 & $12500 \mathrm{ef}$ & $2170.0 \mathrm{e}$ & $12605 \mathrm{~g}$ & $2596.0 \mathrm{def}$ \\
\hline & 50NPSB + 100Urea & $13973 \mathrm{~cd}$ & $3295.7 b$ & $15013 \mathrm{~cd}$ & $3629.1 \mathrm{bc}$ \\
\hline & 100 NPSB+100Urea & $15000 \mathrm{bc}$ & $3913.3 \mathrm{a}$ & $16605 b$ & $4906.7 \mathrm{a}$ \\
\hline & 150 NPSB+100Urea & $16977 \mathrm{a}$ & $3072.0 \mathrm{bc}$ & $17548 \mathrm{a}$ & $4072.0 \mathrm{~b}$ \\
\hline \multirow{4}{*}{ Mekassa-4 } & 0 & $12300 \mathrm{ef}$ & $2162.7 \mathrm{e}$ & $12970 \mathrm{~g}$ & $2108.0 \mathrm{f}$ \\
\hline & 50NPSB + 100Urea & $12400 \mathrm{ef}$ & $2549.3 \mathrm{cde}$ & $13173 \mathrm{fg}$ & 3020.3 de \\
\hline & 100 NPSB+100Urea & $13200 \mathrm{de}$ & $2853.3 \mathrm{bcd}$ & $13307 \mathrm{fg}$ & $3353.3 \mathrm{~cd}$ \\
\hline & 150 NPSB+100Urea & $13967 \mathrm{~cd}$ & $2354.7 \mathrm{de}$ & $14402 \mathrm{de}$ & $2554.7 \mathrm{def}$ \\
\hline \multirow{4}{*}{ Melkassa-6Q } & 0 & $11733 f$ & $2026.7 \mathrm{e}$ & $12403 \mathrm{~g}$ & $2022.7 f$ \\
\hline & 50NPSB+ 100Urea & $13233 \mathrm{de}$ & $2260.0 \mathrm{e}$ & $14003 \mathrm{ef}$ & $3001.3 \mathrm{de}$ \\
\hline & 100 NPSB+100Urea & $14500 \mathrm{bc}$ & $2302.7 \mathrm{de}$ & $14938 \mathrm{cde}$ & $2176.0 \mathrm{ef}$ \\
\hline & 150 NPSB+100Urea & $15300 \mathrm{~b}$ & 2386.7ed & $15739 \mathrm{bc}$ & $2586.7 \mathrm{def}$ \\
\hline $\operatorname{LSD}(0.05)$ & & 1105.9 & 589.11 & 941.80 & 583.99 \\
\hline
\end{tabular}

\subsubsection{Hundred Seed Weight (kg/ha)}

The analysis of variance in the current study revealed that non-significant effects $(\mathrm{P}<0.05)$ among the main effect of varieties and NPSB blended fertilizer rate as well as their interaction on hundred seed weight (Table 4). However, [29]) "obtained that, there were significant differences $(\mathrm{P} \leq 0.05)$ among fertilizers rate on thousand kernel weight of maize at East Wollega Zone of Oromia region". Although there was no significant difference between maize varieties and NPSB blended fertilizer rate, slightly the highest (30.1g) and lowest (29.2 g) hundred seed weight were obtained from Melkassa-2 and Malkassa-6Q varieties, respectively in Dasenech location. While in Nyangatom location the highest (32.0g) and lowest $(31.0 \mathrm{~g})$ average hundred seed weight were obtained and Melkassa-6Q and Melkassa-2 variety, respectively (Table 4$)$. With regards to blended fertilizer, the highest (31.6g) and (24.0 g) average hundred seed weight were obtained from $100 \mathrm{~kg} / \mathrm{ha}$ blended fertilizer rate in Dasenech and Nyangatom location, respectively. While the lowest $(29.3 \mathrm{~g})$ and $(29.2 \mathrm{~g})$ average hundred seed weights were obtained from zero blended fertilizer rates in Dasenech and Nyangatom locations, respectively. This finding was slightly similar with [9]) who found that the lowest thousand seed was obtained from zero blended fertilizer application with compared to fertilizer application.

Table 4. The main effect of the mean value for hundred seed weight and harvest index of sorghum research conducted in south Omo zone during 2020 cropping season.

\begin{tabular}{lllll}
\hline \multirow{2}{*}{ Treatments } & Dasenech location & & Nyangatom location & Harvest index \\
\cline { 2 - 5 } & Hundred seed weight (g) & Harvest index & Hundred seed weight (g) & $0.244 \mathrm{a}$ \\
\hline Varieties & & & & $0.195 \mathrm{~b}$ \\
Melkasa-2 & $30.1 \mathrm{a}$ & $0.213 \mathrm{a}$ & $31.5 \mathrm{a}$ & $0.166 \mathrm{c}$ \\
Melkasa-4 & $32.5 \mathrm{a}$ & $0.192 \mathrm{a}$ & $32.0 \mathrm{a}$ & 0.022 \\
Melkasa-6Q & $29.2 \mathrm{a}$ & $0.164 \mathrm{~b}$ & $31.0 \mathrm{a}$ & $0.177 \mathrm{c}$ \\
LSD (0.05) & 3.808 & 0.023 & 2.74 & $0.191 \mathrm{bc}$ \\
Blended Fertilizer Rate (kg/ha) & & & $29.2 \mathrm{a}$ & $0.223 \mathrm{a}$ \\
0 & $29.3 \mathrm{a}$ & $0.169 \mathrm{~b}$ & $30.9 \mathrm{a}$ & $0.212 \mathrm{ab}$ \\
50NPSB+100Urea & $31.0 \mathrm{a}$ & $0.203 \mathrm{a}$ & $34.0 \mathrm{a}$ & 0.025 \\
100 NPSB+100Urea & $31.6 \mathrm{a}$ & $0.212 \mathrm{a}$ & $31.8 \mathrm{a}$ & \\
150 NPSB+100Urea & $30.6 \mathrm{a}$ & $0.174 \mathrm{~b}$ & 4.16 & \\
LSD $(0.05)$ & 3.242 & 0.026 & & \\
\hline
\end{tabular}

\subsubsection{Harvest Index}

The harvest index is a measure of the physiological productivity potential of a variety. A crop can convert the dry matter into economic yield. The main effects on harvest index were significant for both varieties and plant densities 
$(\mathrm{P}<0.01)$ while, the interaction effect was not significant (Table 4). The maximum harvest index $(0.213)$ and $(0.244)$ were recorded from Melkassa-2 variety at Dasenech and Nyangatom location, respectively and the minimum harvest index (0.164) and (0.166) were recorded from Melkassa-6Q variety at Dasenech and Nyangatom location, respectively. With regards to NPSB blended fertilizer rate, The maximum harvest index (0.212) and (0.223) were recorded from $100 \mathrm{~kg}$ NPSB $\mathrm{kg} / \mathrm{ha}$ at Dasenech and Nyangatom location, respectively and the minimum harvest index (0.169) and (0.177) were recorded from 0 NPSB fertilizer at Dasenech and Nyangatom location, respectively. Similarly, [32] who indicated that there was a significant variation on harvest index due to varieties. [7] also found that different rates of inorganic fertilizer levels had a significant effect on the maize harvest index.

\subsection{Economic Analysis}

The most important step in performing partial budget analysis is the proper identification of data on the costs and benefits associated with the alternative technologies. It is known that farmers apply fertilizer to get a profit. Achieving the goal of yield increment depends not only on the kind and amount of fertilizer but also on the cost of the fertilizer, seed and price of the yields [13]. All variable costs were calculated based on the current price of grain yield, Labor to apply fertilizer and blended fertilizers and urea as per the information obtained from local markets. The cost of Labors were 50 Birr/day, while NPSB and Urea were 17, 16, and 15 Birr $\mathrm{kg}^{-1}$, respectively. The selling price of maize at the local market around the South Omo Zone area was taken as Birr $15 \mathrm{~kg}^{-1}$ for grain yield. The highest net benefit (49229.6 Ethbirr) and MRR value 1 of $(2525.8475 \%)$ was obtained Melkassa-2 variety with treated with $100 \mathrm{~kg}$ ha- ${ }^{1}$ of blended fertilizer rate for Dasenech location (Table 5). While the highest net benefit (62640.45 Eth-birr) and MRR value of (2926.2\%) were obtained Melkassa-2 variety with treated with $100 \mathrm{~kg} \mathrm{ha-}{ }^{1}$ of blended fertilizer rate for Nyangatom location (Table 6). The result shows the highest MRR has the highest net benefit per ha.

Table 5. Summary of partial budget analysis of the effects of blended fertilizer rates rate on maize varieties at Dasenech location.

\begin{tabular}{|c|c|c|c|c|c|c|c|c|}
\hline Varieties & $\begin{array}{l}\text { NPSB Fertilizer } \\
\text { levels (kg/ha) }\end{array}$ & $\begin{array}{l}\text { Av. Yield } \\
\mathrm{kg} / \mathrm{ha}\end{array}$ & $\begin{array}{l}10 \% \text { Adj. } \\
\text { yield }\end{array}$ & $\begin{array}{l}\text { Gross Field } \\
\text { Benefits (ETB/ha) }\end{array}$ & $\begin{array}{l}\text { Total variable } \\
\text { cost }(\mathrm{ETB} / \mathrm{ha})\end{array}$ & $\begin{array}{l}\text { Net Benefit } \\
\text { (ETB/ha) }\end{array}$ & $\begin{array}{l}\text { Dominance } \\
\text { analysis }\end{array}$ & MRR\% \\
\hline \multirow{4}{*}{ Melkassa-2 } & 0 & 2170 & 1953 & 29295.0 & 0 & 29295.0 & $\mathrm{D}$ & \\
\hline & $50 \mathrm{NPSB}+100 \mathrm{Urea}$ & 3295.7 & 2966.13 & 44492.0 & 2,750 & 41742.0 & & 522.963 \\
\hline & 100 NPSB+100Urea & 3913.3 & 3521.97 & 52829.6 & 3,600 & 49229.6 & & 2525.829 \\
\hline & $150 \mathrm{NPSB}+100$ Urea & 3072 & 2764.8 & 41472.0 & 4,450 & 37322.0 & & 1157.124 \\
\hline \multirow{3}{*}{ Mekassa-4 } & 0 & 2162.7 & 1946.43 & 29196.5 & 0 & 29196.5 & $\mathrm{D}$ & \\
\hline & 50NPSB+ 100Urea & 2549.3 & 2294.37 & 34415.6 & 2,750 & 31665.6 & $\mathrm{D}$ & \\
\hline & 150 NPSB+100Urea & 2354.7 & 2119.23 & 31788.5 & 4,450 & 27638.5 & $\mathrm{D}$ & \\
\hline \multirow{4}{*}{ Melkassa-6Q } & 0 & 2026.7 & 1824.03 & 27360.5 & 0 & 27360.5 & $\mathrm{D}$ & \\
\hline & 50NPSB+ 100Urea & 2260 & 2034 & 30510.0 & 2,750 & 27760.0 & $\mathrm{D}$ & \\
\hline & 100 NPSB+100Urea & 2302.7 & 2072.43 & 31086.5 & 3,600 & 27486.5 & $\mathrm{D}$ & \\
\hline & 150 NPSB+100Urea & 2386.7 & 2148.03 & 32220.5 & 4,450 & 28070.5 & $\mathrm{D}$ & \\
\hline
\end{tabular}

Where: Av. Yield $=$ Average yield, $10 \%$ Adj. yield $=$ Adjusted yield, $\mathrm{TVC}=$ Total Variable Cost and MRR $\%=$ marginal rate of return, MRR $=$ change in net income/change in cost x 100 Costs and returns (income) are described in Birr ha.

Table 6. Summary of partial budget analysis of the effects of blended fertilizer rates rate on maize varieties at Nyangatom location.

\begin{tabular}{|c|c|c|c|c|c|c|c|c|}
\hline Varieties & $\begin{array}{l}\text { NPSB Fertilizer } \\
\text { levels (kg/ha) }\end{array}$ & $\begin{array}{l}\text { Av. Yield } \\
\text { kg/ha }\end{array}$ & $\begin{array}{l}10 \% \text { Adj. } \\
\text { yield }\end{array}$ & $\begin{array}{l}\text { Gross Field } \\
\text { Benefits (ETB/ha) }\end{array}$ & $\begin{array}{l}\text { Total variable } \\
\text { cost (ETB/ha) }\end{array}$ & $\begin{array}{l}\text { Net Benefit } \\
\text { (ETB/ha) }\end{array}$ & $\begin{array}{l}\text { Dominance } \\
\text { analysis }\end{array}$ & MRR\% \\
\hline \multirow{3}{*}{ Melkassa-2 } & 0 & 2596 & 2336.4 & 35046 & 0 & 35046 & $\mathrm{D}$ & \\
\hline & 50NPSB+ 100Urea & 3629.1 & 3266.19 & 48992.85 & 2750 & 46242.85 & & 688.596 \\
\hline & 150 NPSB+100Urea & 4072 & 3664.8 & 54972 & 4,450 & 50522 & & 2911.294 \\
\hline \multirow{3}{*}{ Mekassa-4 } & 0 & 2108 & 1897.2 & 28458 & 0 & 28458 & $\mathrm{D}$ & \\
\hline & 50NPSB+ 100Urea & 3020.3 & 2718.27 & 40774.05 & 2750 & 38024.05 & $\mathrm{D}$ & \\
\hline & 150 NPSB+100Urea & 2554.7 & 2299.23 & 34488.45 & 4,450 & 30038.45 & $\mathrm{D}$ & \\
\hline \multirow{4}{*}{ Melkassa-6Q } & 0 & 2022.7 & 1820.43 & 27306.45 & 0 & 27306.45 & $\mathrm{D}$ & \\
\hline & 50NPSB+ 100Urea & 3001.3 & 2701.17 & 40517.55 & 2750 & 37767.55 & $\mathrm{D}$ & \\
\hline & 100 NPSB+100Urea & 2176 & 1958.4 & 29376 & 3600 & 25776 & $\mathrm{D}$ & \\
\hline & 150 NPSB+100Urea & 2586.7 & 2328.03 & 34920.45 & 4,450 & 30470.45 & $\mathrm{D}$ & \\
\hline
\end{tabular}

\section{Conclusion and Recommendation}

The yield of maize in Ethiopia including South Omo Zone is low mainly attributed to several production constraints among them, lack of improved varieties, pest, fertilizer rate and types.

The current study was carried out to investigate the effects of NPSB blended fertilizer levels for maize yield production at Dasenech and Nyangatom districts in the lowland area of South Omo Zone during the 2019/ 2020 cropping season. The experiment was factorial with three maize varieties (Melkassa- 
6Q, Melkassa-4 and Melkassa-2) and four NPSB blended fertilizer rates including $\mathrm{kg} \mathrm{ha}^{-1}$ (none fertilizer. 50NPSB, 100NPSB, and 150 NPSB). The experiment was conducted using a randomized complete block design with three replications. Phonological and growth parameters, as well as yield and yield components data, were collected and subjected to analysis of variance using the SAS software program. The result of analysis of variance revealed that the interaction effect of varieties with blended fertilizer rate highly significant difference in grain yield. The result indicated that the highest grain yield (3913.3 $\left.\mathrm{kg} \mathrm{ha}^{-1}\right)$ and net benefit (49,229.6 Eth-birr ha $\left.{ }^{-1}\right)$ with MRR of $2525.83 \%$ were obtained from Melkassa-2 variety treated with $100 \mathrm{~kg} \mathrm{ha}^{-1}$ of NPSB fertilizer rates at Dasenech location. Whereas, at Nyangatom location, the highest grain yield (4906.7 $\mathrm{kg} \mathrm{ha}^{-1}$ ) and net benefit (62640.45Eth-birr ha ${ }^{-1}$ ) with MRR of $2926.2 \%$ were obtained from similar Melkassa-2 variety treated with similar $100 \mathrm{~kg} \mathrm{ha}^{-1}$ of NPSB blended fertilizer rates. Therefore, based on the yield response and economic analysis indicate that Makassar-2 varieties treated with $100 \mathrm{~kg} \mathrm{ha}^{-1}$ of NPSB blended fertilizer can be recommended for both location and other similar agro-ecologies is economically feasible levels to maximize maize production.

\section{Conflicts of Interest}

The authors pronounce that there are no encounters of interest regarding the publication of this paper.

\section{Acknowledgements}

The authors are grateful to the international development enterprise (iDE) for giving fud budget to carried out this research work and also thanks to Jinka Agricultural Research Center for support by vehicle and agricultural impute and provision of so many facilities.

\section{References}

[1] Dowswell, C. R, R. L Paliwal and R. P. Cantrell 1996. Maize in $3 r d$ World. West Views press, Inc. Colorado, USA.

[2] Haffanaghel, H. P. 1961. Agriculture in Ethiopia. FAO, Rome.

[3] FAOSTAT (Food and Agriculture Organization Corporate Statistical Database). 2017. Statistical databases and data-sets of the Food and Agriculture Organization of the United Nations. http://faostat.fao.org/default.aspx.

[4] Akalu T. 2015. On-farm Evaluation of Improved Maize Varieties in https://www.researchgate.net/publication/237309549. Ethiopia.

[5] CSA (Central Statistical Agency). 2017. Report on area and production of crops (private peasant holdings 'Meher' season) 2016/2017. Addis Ababa Ethiopia, the FDRE statistical bulletin, Vol. I. Statistical Bulletin 584, Addis Ababa Ethiopia, April 2017. Pp. 1-12.

[6] MOANR (Ministry of Agriculture and Natural Resources). 2017. Plant variety release, protection and seed quality control directorate. Addis Abeba, Ethiopia.
[7] Orkaido Olte (2004) Effects of Nitrogen and Phosphorus Fertilizers on Yield And Yield Components of Maize (Zea Mays L.) on Black Soil of Regede Konso Alemaya University at Konso special wereda, southern Ethiopia. M.Sc. Thesis Presented to Haramaya University, Ethiopia.

[8] Delorite, R. J. and H. L. Ahlgren. 1967. Crop production. $3^{\text {rd }}$ (ed.). Prentice Hall, Inc., Englewood Cliffs, New Jersey.

[9] Onasanya, R. O., Aiyelari, O. P., Onasanya, A. S., Oikeh, F. E., \& Oyelakin, O. O. (2009). Growth and yield response of maize (Zea mays L.) to different rates of nitrogen and phosphorus fertilizers in Southern Nigeria. IDOSI Publications, 5 (4), 400-407.

[10] Chimdessa, D. (2016). Blended fertilizers effects on maize yield and yield components of Western Oromia, Ethiopia. Agriculture, Forestry and Fisheries, 5 (5), 151-162. https://doi.org/10.11648/j.aff.20160505.13.

[11] Bouyoucos J (1962). Hydrometer method improved for making particle size analysis of soil. Agronomy Journals 54: 464-465.

[12] Van Reeuwijk, L. P., 1992. Procedures for soil analysis, 3rd Ed. International Soil Reference and Information Center (ISRIC), Wageningen, the Netherlands. 34p.

[13] Black, C. A, 1965. Methods of soil analysis. Part I, American Society of Agronomy. Madison, Wisconsin, USA. 1572p.

[14] Ranst, V. E., M. Verloo, A. Demeyer and J. M. Pauwels, 1999. Manual for the Soil Chemistry and Fertility Laboratory. Belgium. 245p.

[15] Olsen R, Cole S, Watanabe F, Dean L (1954). Estimation of available phosphorus in soils by extraction with sodium bicarbonate. United States Department of Agriculture Circ. 939.

[16] USDA (United States Department of Agriculture), 1984. Procedures for Collecting Soil Samples and Methods of Analysis for Soil Survey. Soil Survey. Invest. Rep. 1. (Rev.) U.S. Gov. Print Office, Washington, DC.

[17] Kenneth Hellevang. 1995. Grain Moisture Content Effects and Management. North Dakota State Extension Publication AE905.

http://www.ag.ndsu.edu/extensionaben/documents/ae905.pdf. [Accessed March 2021].

[18] Donald C. M., 1962. In search of yield. Journal of Australian Institute of Agricultural Science, 28: 171-178. Egbe O., Alibo S. and Nwueze I. 2010. Evaluation of some extra-early and early maturing cowpea varieties for intercropping with maize in Southern Guinea Savanna of Nigeria. Agriculture and Biology Journal, 1: 845-458.

[19] SAS (Statistical Analysis System). 2008. Statistical Analysis System. SAS institute version 9.20 Cary, NC, USA.

[20] CIMMYT (Centro Internacional de Mejoramiento de Maiz y Trigo/International Maize and Wheat Improvement Center). (1988). from agronomic data to farmer's recommendations: an economics training manual. Completely revised edition, CIMMYT, Mexico. D. F. 79 pp.

[21] Ethio SIS. 2014. Soil fertility status and fertilizer recommendation atlas for Tigray regional state, Ethiopia. July 2014, Addis Ababa, Ethiopia. Ethio SIS. 2015. http://www.ata.gov.et/highlighted-deliverables/ethiopian-soilinformation-system-ethiosis/. Date accessed: 19 March 2021. 
[22] Tekalign M (1991). Soil, plant, water, fertilizer, animal manure and compost analysis. Working Document No. 13. International Livestock Research Center for Africa, Addis Ababa.

[23] Berry, D. P., Dillon, P., Rath, M. and Horan, B., 2007. Influence of Holstein-Friesian strain and feed system on body weight and body condition score lactation profiles. Journal of Dairy Science, 90 (4), pp. 1859-1869.

[24] FAO (Food and Agricultural Organization). 2014. The world reference base for soil resources. International soil classification system for naming soils and creating legends for soil maps. World Soil Resources Reports No. 106. FAO, Rome.

[25] Kinfe Tekulu, Tsadik Tadele, Tewolde Berhe, Weldegebreal Gebrehiwot, Gebresemaeti Kahsu, Solomon Mebrahtom and Goitom Aregawi. 2019. Evaluation of NPSZnB fertilizer levels on yield and yield component of maize (Zea mays L.) at Laelay Adiyabo and Medebay Zana districts, Western Tigray, Ethiopia. Journal of Cereals and Oilseeds. Vol. 10 (2), pp. 5463.

[26] Jeet, S., Singh, J. P., Kumar, R., Prasad, R. K., Kumar, P., Kumari, A. and Prakash, P., 2012. Effect of nitrogen and Sulphur levels on yield, economics and quality of QPM hybrids under dryland conditions of Eastern Uttar Pradesh, India. Journal of Agricultural Science, 4 (9), Pp. 31.

[27] Mekuannet Belay and Kiya Adare (2020). Response of growth, yield components, and yield of hybrid maize (Zea mays L.) varieties to newly introduce blended NPS and N fertilizer rates at Haramaya, Eastern Ethiopia. Cogent Food \& Agriculture. 6 : 1771115. https://doi.org/10.1080/23311932.2020.1771115

[28] Tolera A, Tolessa D and Dagne W. (2017). Effects of Varieties and Nitrogen Fertilizer on Yield and Yield Components of Maize on Farmers Field in Mid Altitude Areas of Western Ethiopia. International Journal of Agronomy. https://doi.org/10.1155/2017/4253917.

[29] Singh, R., \& Daoudi, M. (2017). Effect of nitrogen and Sulphur on growth and yield of hybrid maize (Zea mays L.). International Journal of Current Microbiology and Applied Sciences, $\quad 6 \quad$ (6), $1930-1935$ https://doi.org/10.20546/ijcmas.2017.606.22

[30] Dagne C (2016). Blended fertilizers effects on maize yield and yield components of Western Oromia, Ethiopia. Agriculture, Forestry and Fisheries 5 (5): 151-162. doi: 10.11648/jaff.20160505.13.

[31] Jafer D 2018. Validation of blended fertilizer for maize production under limed condition of acid soil. Journal of Natural Sciences Research 8 (23): 52-58.

[32] Ahmad, A., Usman, M., Ullah, E., \& Warraich, E. A. (2003). Effects of different phosphorus levels on the growth and yield of two cultivars of maize (Zea mays L.). International Journal of Agriculture \& Biology, 5 (4), 632-634. http://www.ijab.org 